\title{
Sentinel Lymph Node Biopsy
}

\section{A new approach in the management of head and neck cancers}

"Deepti Sharma, George Koshy, Sonal Grover, Bhushan Sharma

$$
\text { خزجة العقدة الليمفاوية الخافرة }
$$

\begin{abstract}
Cervical lymph node metastasis affects the prognosis and overall survival rate of and therapeutic planning for patients with head and neck squamous cell carcinomas (HNSCCs). However, advanced diagnostic modalities still lack accuracy in detecting occult neck metastasis. A sentinel lymph node biopsy is a minimally invasive auxiliary method for assessing the presence of occult metastatic disease in a patient with a clinically negative neck. This technique increases the specificity of neck dissection and thus reduces morbidity among oral cancer patients. The removal of sentinel nodes and dissection of the levels between the primary tumour and the sentinel node or the irradiation of target nodal basins is favoured as a selective treatment approach; this technique has the potential to become the new standard of care for patients with HNSCCs. This article presents an update on clinical applications and novel developments in this field.
\end{abstract}

Keywords: Head and Neck Cancer; Squamous Cell Carcinomas; Neck Dissection; Sentinel Lymph Node Biopsy; Lymphoscintigraphy.

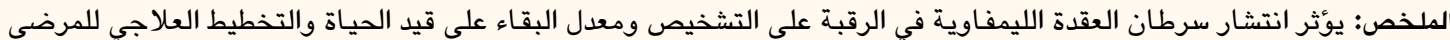

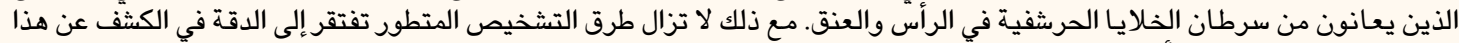

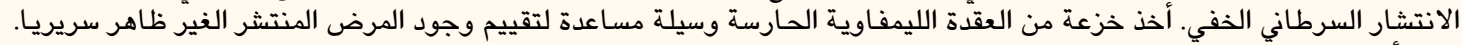

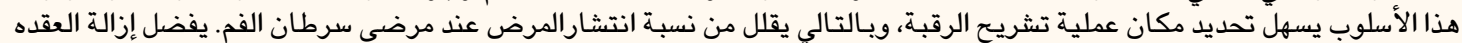

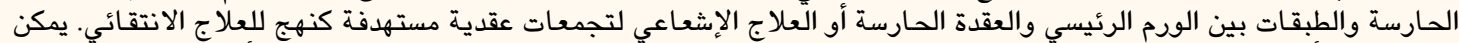

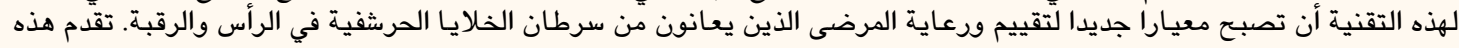

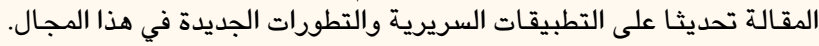

$$
\begin{aligned}
& \text { الكلمات المفتاحية: سرطان الرأس والعنق؛ سرطان الخلايا الحرشفية؛ تشريح العنق؛ خزعة العقدة الليمفاوية الخافرة؛ تصويرالعقد } \\
& \text { اللمفاوية الحارسة. }
\end{aligned}
$$

A

S OPPOSED TO PRIMARY TUMOURS, METASTASIS

is responsible for the high mortality rate

of most cancer patients; moreover, cancer cells primarily invade the regional lymph nodes before spreading to other parts of the body. ${ }^{1}$ Genetic instability results in tumour cell heterogeneity, leading to the emergence of metastatic clones and dissemination of the cancer from the primary tumour site. ${ }^{2}$ Malignant cells metastasise due to an interaction between the host factors and tumour cells. Genes related to the extracellular matrix, adhesion, motility and protease inhibition constitute a significant part of the metastatic process. ${ }^{3}$

\section{Nodal Metastasis}

\section{NODAL METASTATIC CASCADE}

The migration and invasion of cancer cells into the lymphatic system is governed by a variety of intricate genotypic, phenotypic and microenvironmental processes. After entering the lymphatic draining channels, the tumour cells metastasise to the regional lymph nodes in the neck and form the metastatic foci. ${ }^{4}$ Macrometastases refer to lymph nodes that appear suspicious on clinical or radiographical examinations; in contrast, nodal metastases-which are not detectable by imaging methods or physical examination-indicate occult or subclinical metastasis. Hermanek microscopically differentiated occult metastases into macrometastases (metastatic deposits of $>2 \mathrm{~mm}$ ), micrometastases (metastatic deposits of $<2 \mathrm{~mm}$ ) and isolated or small clusters of tumour cells (metastatic deposits of $<0.2 \mathrm{~mm}$ ). ${ }^{5}$ Isolated tumour cells (ITCs) can also be defined as a cluster of $\leq 200$ tumour cells visible on one histology slide; these cells can further be categorised into those detectable by light microscopy, immunohistochemistry or molecular methods. ${ }^{6}$ Chemoradiation or elective neck dissection (END) should be considered in patients 
with ITCs or those with a high risk of occult micrometastasis.?

The microenvironment of the lymph node is initially hostile to cancer cells due to a predominance of immune effector cells and cytokines; immunoresistant clones in the hostile lymph node milieu subsequently proliferate, spread and invade the rest of the lymphatic system to establish metastasis. ${ }^{8}$ Malignant cells follow an orderly sequence, spreading from one nodal basin to the next as the disease progresses down the neck. In some situations, lymph node groups can be bypassed, which can result in a process known as skip metastasis. ${ }^{9}$ However, controversial reports exist as to whether lymphatic tumours spread through new lymphatic vessels (i.e. lymphangiogenesis) or pre-existing peritumoural lymphatic vessels. ${ }^{10}$ Different molecular components are also involved in the metastatic cascade, including prospero homeobox 1, lymphatic vessel endothelial hyaluronan receptor 1 , podoplanin, vascular endothelial growth factor receptor-3, epithelial cadherin, catenins, syndecans, focal adhesion kinase, matrix metalloproteinases-2 and -9, metallothioneins and laminins. ${ }^{11}$ These markers have recently been explored as a result of increased research interest in tumour lymphatics. ${ }^{12}$

\section{A SIGNIFICANT PROGNOSTIC FACTOR}

Lymph nodes in the head and neck constitute approximately $30 \%$ of the 800 lymph nodes in the human body. ${ }^{13}$ Neck node metastasis is a major determinant in the prognosis of oral, oropharyngeal and other head and neck cancers; the disease-free survival rate decreases to approximately 50\% with the presence of a single cancer-positive lymph node. ${ }^{14}$ The extent of lymph node involvement should be considered as an indirect index of the systemic tumour load and is an important aspect of tumour staging; thus, the size, level and presence of a metastatic neck node determines overall survival and treatment planning. ${ }^{15}$ In patients with oral cancer, the lymph node levels I to III are most commonly involved. ${ }^{16}$ The frequency of skip metastasis to levels IV or $\mathrm{V}$, bypassing the upper nodal levels, is approximately $4-5 \%$ in oral cancer, although this can increase to $16 \%$ in the tongue. ${ }^{17}$ A clinically negative neck indicates a primary tumour of either $\leq 2 \mathrm{~cm}$ or $2-4 \mathrm{~cm}$ with no regional lymph node metastasis (N0). ${ }^{18}$ The incidence of occult neck metastasis in stage I/II disease for patients with clinically negative necks is $30-34 \% .^{12,19}$ The traditional approach to treatment has been to proceed with wide-margin radical neck surgery. However, prophylactic END for all patients with carcinomas of the oral cavity and a clinically negative neck results in an overtreatment rate of $65-70 \%$; nevertheless, overall survival may be jeopardised if the carcinoma is not treated..$^{20}$

Predictive factors associated with occult metastasis of the cervical nodes include primary tumour site, size, degree of differentiation, perineural and vascular invasion, inflammatory response and tumour ploidy status. ${ }^{21}$ Advanced diagnostic approaches with greater accuracy are required, since these factors alone or along with conventional methods are insufficient to assess neck metastasis. ${ }^{13}$ Advanced imaging modalities such as computed tomography, magnetic resonance imaging, ultrasonography, positron emission tomography (PET), lymphoscintigraphy and ultrasoundguided fine-needle aspiration cytology are often used for neck evaluation and screening in patients with oral cancer. Nonetheless, these approaches can fail to detect occult neck metastasis and subcentimetric or microscopic metastatic foci. ${ }^{22}$

For patients presenting clinically without regional disease, treatment approaches for oral squamous cell carcinoma (OSCC), and head and neck cancers in general, have been debated. ${ }^{23}$ In cases of more advanced oral cancer, clinically evident and diagnostically proven locoregional metastasis give a clearcut indication for treatment of the neck, based on the treatment approach for the primary tumour. ${ }^{24}$ However, the management of patients with stage I/II disease and a NO neck remains unclear; patients can be treated either with prophylactic END, irradiation or observation with regular follow-ups. ${ }^{14}$ A surveillance approach can result in poor survival and increased risk of occult metastasis. ${ }^{25}$ However, performing ENDs on all patients with NO necks would lead to undue surgeries with large incisions, skin flaps and scars, the sacrifice of the spinal accessory nerve and the involvement or sacrifice of the sternocleidomastoid muscle and internal jugular vein, particularly if the surgery is bilateral. ${ }^{26}$ Neck dissection could also lead to other sequelae, including shoulder and neck dysfunction, pain, contour changes, haemorrhage, nerve injury, lower lip paresis, lymphoedema, an increased need for postoperative radiotherapy, poor cosmetic outcomes and greater expenses. ${ }^{27}$

\section{Sentinel Lymph Node Biopsy}

\section{A NOVEL APPROACH}

Recently, the concept of a sentinel lymph node (SLN) was introduced in head and neck squamous cell carcinomas (HNSCCs) in order to more precisely 


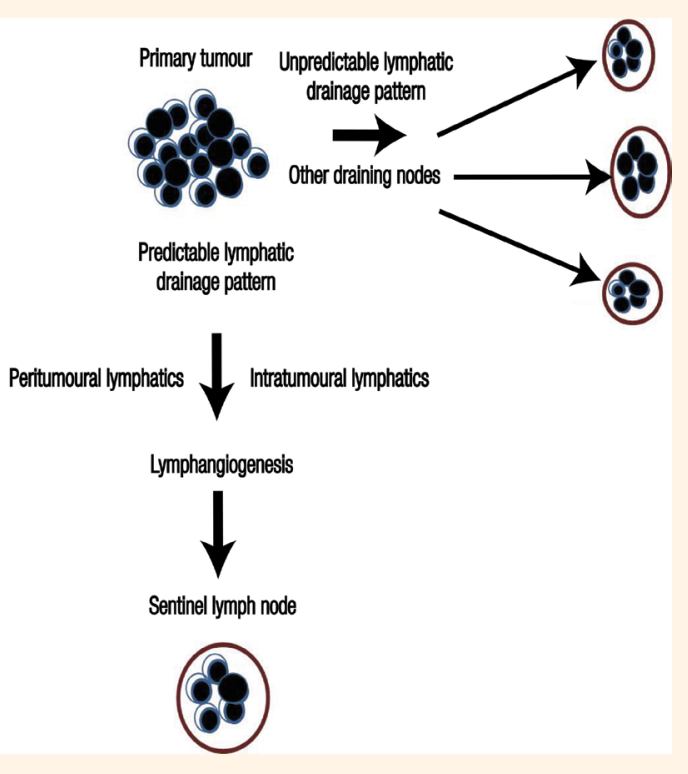

Figure 1: Flowchart depicting the process of primary tumour spread to a sentinel lymph node.

detect and evaluate neck metastasis and unpredictable lymphatic drainage patterns, following its successful application in melanomas and breast cancer. ${ }^{22,28}$ Several validation studies involving ENDs have resulted in SLN cancer detection rates of $>95 \% .^{12}$ Following the orderly and sequential drainage in the lymphatic stream from the tumour site, the first node reached is the SLN, which could help predict the nodal stage of metastasis [Figure 1]. In theory, if the SLN is free from cancer cells, then distal node involvement is assumed to be rare. ${ }^{29}$ Thus, the lymphatic basin status can be ascertained along with a reduction in poor prognosis and morbidity rates. ${ }^{28,30}$

A SLN biopsy is an ancillary diagnostic method for assessing the presence of occult metastatic disease in a N0 neck. This minimally invasive technique eliminates the need for a neck dissection, which until recently was thought to be the only means of neck staging. ${ }^{31}$ A SLN biopsy is a selective procedure based on the identification and evaluation of echelon nodes (i.e. first station or levels I and II) for metastatic spread; hence, the first drainage node or group of nodes, known as the SLN, are chosen for dissection as the location at which a primary tumour first metastasises. ${ }^{14}$ In 1996, the first successful SLN biopsy was performed by Alex et al. on a patient with a laryngeal supraglottic carcinoma; Koch et al. subsequently proved the feasibility of this procedure in 1998 for selected patients with head and neck mucosal lesions. ${ }^{27}$ Morton et al. found that selective lymphatic dissection performed after a SLN biopsy was therapeutically equivalent to a comprehensive elective lymphatic dissection among patients with skin melanomas. ${ }^{32}$

\section{TREATMENT PROTOCOLS}

In recent decades, improved understanding of lymphatic drainage patterns in the head and neck region have simplified the assessment of higher risk nodal levels. ${ }^{27}$ There has been a gradual shift towards a more conservative/selective surgical approach for patients with clinically negative necks, progressing from radical neck dissection to modified radical neck dissection and subsequently selective neck dissection. ${ }^{33}$ The techniques and methodology for SLN identification in head and neck cancers have been widely debated and are still under investigation [Tables 1 and 2]. 5,14,15,22,24,27-31,34-46

Shoaib et al. suggested a protocol involving preoperative lymphoscintigraphy, intraoperative blue dye and gamma probe localisation [Figure 2]..$^{30}$ This technique is based on observing the route of lymphatic flow via imaging after the injection of a radioactive contrast agent near the primary tumour. ${ }^{42}$ The flow and direction of the lymph, comparable to the possibly metastatic flow from the tumour, can be visualised preoperatively by means of lymphoscintigraphy or single-photon emission computed tomography (SPECT). Lymphoscintigraphy reveals SLNs associated with the primary tumour, unexpected lymphatic drainage patterns and lymphatic vessels associated with different lymphatic drainage basins. ${ }^{14}$ To enhance the detection rate, blue dye is often used in combination with radioisotopes. ${ }^{47}$ During the surgery, a handheld gamma probe is used for radionuclide detection to trace the SLN perioperatively and a gamma camera is used for dynamic monitoring of lymphatic drainage. The site of the radioactive lymph nodes, which are important anatomical landmarks, are marked using a gamma camera and the ex vivo radioactivity of the nodes and surgical bed is checked after removing the nodes. ${ }^{31}$

Histopathological evaluation, immunohistochemistry and molecular markers have been suggested for a small number of harvested SLNs to help detect occult metastasis in serial lymph node sections, including molecular techniques such as polymerase chain reaction and immunohistochemistry using cytokeratin markers. ${ }^{43}$ These could potentially lead to more accurate nodal staging and the detection of nodal micrometastatic deposits and ITCs. ${ }^{48}$ It has been suggested that step serial sectioning at $150 \mu \mathrm{m}$ intervals with pan-cytokeratin enhances nodal detection by approximately $20 \%$ in comparison to the initial routinely stained section. ${ }^{15}$ Murer et al. reported lower postoperative morbidity rates and better shoulder function following a SLN biopsy in comparison to an END. ${ }^{49}$ Hernando et al. observed 
Table 1: Literature review of studies regarding lymph node identification and the utility of a sentinel lymph node biopsy in the management of head and neck cancers $22,24,28,29,31,34-41$

\begin{tabular}{|c|c|c|c|c|c|}
\hline $\begin{array}{l}\text { Author and } \\
\text { year of study }\end{array}$ & $\mathbf{N}$ & Lymphatic mapping method & SEN/SPEC & Association & Conclusion \\
\hline $\begin{array}{l}\text { Werner et al. } \\
\text { (2002) }\end{array}$ & 90 & $\begin{array}{l}{ }^{99 \mathrm{~m}} \mathrm{Tc} \text { nanocolloidal injection } \\
\text { during lymph node dissection }\end{array}$ & SEN: $89 \%$ & - & $\begin{array}{l}\text {-Serial sectioning may serve to increase the } \\
\text { diagnostic reliability of a limited ND } \\
\text { - There is a need to remove all radioactive SLNs }\end{array}$ \\
\hline $\begin{array}{l}\text { Chikamatsu et al. } \\
\text { (2004) }\end{array}$ & 11 & $\begin{array}{l}\text { LSG }\left({ }^{99 \mathrm{~m}} \mathrm{Tc} \text {-labelled colloidal }\right. \\
\text { rhenium sulphide), gamma } \\
\text { probe and gamma camera } \\
\text { for radiolocalisation and } \\
\text { monitoring }\end{array}$ & SPEC: $100 \% *$ & NPV: $100 \%$ & $\begin{array}{l}\text {-A ND is not necessary for patients with a N0 neck } \\
\text { as determined by a SLN biopsy, even if a physical } \\
\text { examination or imaging is positive for lymph node } \\
\text { metastasis }\end{array}$ \\
\hline $\begin{array}{l}\text { Alvarez Amézaga } \\
\text { et al. }{ }^{29}(2007)\end{array}$ & 25 & $\begin{array}{l}\text { LSG (colloidal human serum } \\
\text { albumin), vital dye and gamma } \\
\text { probe }\end{array}$ & $\begin{array}{l}\text { SEN: } 93.4 \% \\
\text { SPEC: } 100 \%\end{array}$ & OR: 183.71 & $\begin{array}{l}\text {-Due to its high SEN, a SLN biopsy can be } \\
\text { performed even in the initial stages of OSCC }\end{array}$ \\
\hline $\begin{array}{l}\text { Stefanicka et al. }{ }^{31} \\
(2010)\end{array}$ & 12 & $\begin{array}{l}\text { LSG }\left({ }^{99 m} \text { Tc-labelled }\right. \\
\text { radiocolloidal human } \\
\text { serum albumin), gamma } \\
\text { probe and gamma camera } \\
\text { for radiolocalisation and } \\
\text { monitoring }\end{array}$ & SEN: $100 \%$ & NPV: $100 \%$ & $\begin{array}{l}\text {-Identification of SLNs in patients with OSCCs is } \\
\text { technically feasible and accurate and can predict } \\
\text { occult metastasis }\end{array}$ \\
\hline $\begin{array}{l}\text { Civantos et al. }{ }^{28} \\
(2010)\end{array}$ & 140 & $\begin{array}{l}\text { LSG }\left({ }^{99 \mathrm{~m}} \mathrm{Tc} \text { colloidal sulphur }\right) \\
\text { and gamma probe for } \\
\text { radiolocalisation }\end{array}$ & - & NPV: $96 \%$ & $\begin{array}{l}\text {-A SLN biopsy with step sectioning and } \\
\text { immunohistochemistry correctly predicts a } \\
\text { pathologically-confirmed N0 neck }\end{array}$ \\
\hline $\begin{array}{l}\text { Broglie et } a l .{ }^{36} \\
(2011)\end{array}$ & 79 & $\begin{array}{l}\text { LSG, SPECT and intraoperative } \\
\text { use of a handheld gamma } \\
\text { probe }\end{array}$ & - & - & $\begin{array}{l}\text {-A SLN biopsy can help to select patients with stage } \\
\text { I/II OSCC and occult lymph node disease for an } \\
\text { elective ND } \\
\text { - The occult metastasis recurrence rate in SLN- } \\
\text { negative patients is superior to that of SLN-positive } \\
\text { patients }\end{array}$ \\
\hline $\begin{array}{l}\text { Melkane et al. }{ }^{24} \\
(2012)\end{array}$ & 53 & $\begin{array}{l}\text { LSG }\left({ }^{99 \mathrm{~m}} \mathrm{Tc} \text {-labelled colloidal }\right. \\
\text { rhenium sulphur) and gamma } \\
\text { probe for radiolocalisation }\end{array}$ & - & NPV: $95.2 \%$ & $\begin{array}{l}\text {-A SLN biopsy may be an excellent staging method } \\
\text { in early oral cancers } \\
\text { - Routinely undiagnosed micrometastasis may also } \\
\text { be clinically significant }\end{array}$ \\
\hline $\begin{array}{l}\text { Borbón-Arce } \\
\text { et al. }{ }^{37}(2014)\end{array}$ & 25 & $\begin{array}{l}\text { LSG (hybrid tracer with ICG } \\
\text { dye and a }{ }^{99 m} \text { Tc nanocolloid) } \\
\text { followed by SPECT two hours } \\
\text { later, a portable gamma camera } \\
\text { with a NIR fluorescence } \\
\text { camera and a handheld gamma } \\
\text { ray probe for detection }\end{array}$ & - & - & $\begin{array}{l}\text {-A multimodal approach resulted in the } \\
\text { identification of } 26 \% \text { additional SLNs compared to a } \\
\text { traditional method }\end{array}$ \\
\hline $\begin{array}{l}\text { Rigual et al. } .^{38} \\
(2013)\end{array}$ & 38 & $\begin{array}{l}\text { Preoperative LSG with } \\
\text { intraoperative gamma probe } \\
\text { localisation }\end{array}$ & SEN: $71 \%$ & NPV: $94 \%$ & $\begin{array}{l}\text { - Most patients with positive SLN biopsy results also } \\
\text { had additional positive nodes on ND } \\
\text { - There was a low rate of isolated neck recurrence } \\
\text { among patients with negative SLN biopsy results } \\
\text { - Patients with negative SLN biopsy results had } \\
\text { better overall/disease-specific survival rates }\end{array}$ \\
\hline $\begin{array}{l}\text { Milenović et al. }{ }^{34} \\
(2014)\end{array}$ & 30 & $\begin{array}{l}\text { LSG and ultrasound-guided } \\
\text { puncture of the lymph nodes, } \\
\text { gamma probe and gamma } \\
\text { camera for radiolocalisation }\end{array}$ & SEN: $93 \%$ & - & $\begin{array}{l}\text {-A SLN biopsy should be performed in selected } \\
\text { cases, as it is sometimes easier to perform a ND in } \\
\text { certain localisations }\end{array}$ \\
\hline Flach et al. ${ }^{39}$ (2014) & 62 & $\begin{array}{l}\text { Preoperative LSG, blue dye and } \\
\text { intraoperative gamma probe } \\
\text { for detection }\end{array}$ & SEN: $80 \%$ & NPV: $88 \%$ & $\begin{array}{l}\text {-A SLN biopsy reduces occult lymph node } \\
\text { metastasis risk in T1/T2 oral cancer ( } 40 \% \text { versus } 8 \% \text { ) } \\
\text {-Patients with negative SLNs and no elective ND } \\
\text { achieve an excellent rate of occult metastasis } \\
\text { recurrence with a SLN biopsy which compares } \\
\text { favourably with primary elective ND outcomes }\end{array}$ \\
\hline $\begin{array}{l}\text { Den Toom et al. }{ }^{40} \\
(2015)\end{array}$ & 90 & $\begin{array}{l}\text { Preoperative LSG and } \\
\text { intraoperative blue dye and } \\
\text { gamma probe for detection }\end{array}$ & SEN: $93 \%$ & NPV: $97 \%$ & $\begin{array}{l}\text {-A SLN biopsy is a reliable diagnostic staging } \\
\text { technique for early-stage N0 oral cancer }\end{array}$ \\
\hline $\begin{array}{l}\text { Salazar-Fernandez } \\
\text { et al. }{ }^{41}(2015)\end{array}$ & 96 & Cervical LSG and SPECT & SEN: $88 \%$ & NPV: $94 \%$ & $\begin{array}{l}\text {-A SLN biopsy is an excellent OSCC staging method } \\
\text { - There is a small risk of additional lymph node } \\
\text { metastasis with SLN micrometastasis }\end{array}$ \\
\hline
\end{tabular}

SEN = sensitivity; SPEC = specificity; ${ }^{9 m}$ Tc = technicium $-99 m ; N D=$ neck dissection; SLN = sentinel lymph node; LSG = lymphoscintigraphy; NPV = negative predictive value; $N O=$ without regional lymph node metastasis; $O R=$ odds ratio; $O S C C=$ oral squamous cell cancer; SPECT = single-photon emission computed tomography; ICG = indocyanine green; NIR = near-infrared; $T 1=$ primary tumour of $\leq 2 \mathrm{~cm} ; T 2=$ primary tumour of $2-4 \mathrm{~cm}$.

*For all NO patients. 
Table 2: Indications, contraindications, advantages and disadvantages of a sentinel lymph node biopsy $y^{5,14,15,27-30,42-46}$

\begin{tabular}{|c|c|c|}
\hline Indications & Contraindications & Advantages \\
\hline $\begin{array}{l}\text {-For patients with } \\
\text { T1/T2/N0 head and } \\
\text { neck tumours }\end{array}$ & \multirow{2}{*}{$\begin{array}{l}\text {-For clinically positive } \\
\text { neck nodes, as } \\
\text { metastatic involvement } \\
\text { interferes with the } \\
\text { normal lymph node } \\
\text { architecture, leading } \\
\text { to anomalous draining } \\
\text { patterns }\end{array}$} & $\begin{array}{l}\text {-Allows the accurate detection and } \\
\text { staging of SLN metastasis with } \\
\text { minimal morbidity as the technique } \\
\text { is minimally invasive }\end{array}$ \\
\hline $\begin{array}{l}\text { To assess bilateral } \\
\text { T1/T2/N0 primary } \\
\text { head and neck } \\
\text { tumours close to or } \\
\text { crossing the midline }\end{array}$ & & $\begin{array}{l}\text {-Guides decision-making during } \\
\text { the management of head and neck } \\
\text { tumours }\end{array}$ \\
\hline \multirow{4}{*}{$\begin{array}{l}\text { To clarify the need } \\
\text { for contralateral } \\
\text { dissection in tumours } \\
\text { with one clinically } \\
\text { positive side close to } \\
\text { the midline }\end{array}$} & \multirow{4}{*}{$\begin{array}{l}\text {-For patients with } \\
\text { a history of prior } \\
\text { surgeries or treatments } \\
\text { that may have altered } \\
\text { normal lymphatic } \\
\text { drainage patterns }\end{array}$} & $\begin{array}{l}\text { - Limits the necessity of performing } \\
\text { prophylactic END for all patients }\end{array}$ \\
\hline & & $\begin{array}{l}\text { - Prevents the unnecessary removal of } \\
\text { functional nodes }\end{array}$ \\
\hline & & -Allows selective excision of the SLN \\
\hline & & -Allows adequate assessment of \\
\hline \multirow{7}{*}{$\begin{array}{l}\text {-To ensure accurate } \\
\text { radiocolloid } \\
\text { application in well } \\
\text { accessible primary } \\
\text { tumours }\end{array}$} & \multirow{3}{*}{$\begin{array}{l}\text {-For pregnant or } \\
\text { lactating patients, as } \\
\text { the extent of the SLN } \\
\text { biopsy may need to be } \\
\text { modified to minimise } \\
\text { the risk of radiation } \\
\text { exposure and blue dye } \\
\text { injections }\end{array}$} & $\begin{array}{l}\text { the nodal status of the remaining } \\
\text { neck tissue with a subsequent } \\
\text { histopathological examination }\end{array}$ \\
\hline & & $\begin{array}{l}\text { - Helps to identify skip metastasis, } \\
\text { micrometastasis and unpredictable } \\
\text { lymphatic drainage patterns }\end{array}$ \\
\hline & & $\begin{array}{l}\text {-Improves the histological evaluation } \\
\text { of surgical specimens }\end{array}$ \\
\hline & \multirow[t]{4}{*}{$\begin{array}{l}\text { - For large primary } \\
\text { tumours which can } \\
\text { directly compress the } \\
\text { draining lymphatic } \\
\text { vessels }\end{array}$} & $\begin{array}{l}\text { - Reduces the number of lymph nodes } \\
\text { required for a detailed history and } \\
\text { physical examination in comparison } \\
\text { to an END }\end{array}$ \\
\hline & & -Saves time and expense \\
\hline & & - Shortens the recovery period \\
\hline & & •For medically fit patients \\
\hline
\end{tabular}

Disadvantages
-May be difficult as the approach is
technique-sensitive
-The use of blue dye may elicit an
allergic response
-False-negatives can occur due
to uneven radionuclide injection,
the obscuring of the SLN by the
radioactive signal of the primary
tumour and the obstruction of
the lymphatic vessels by the gross
tumour, resulting in a redirection of
lymphatic flow
-The accuracy of this technique in
identifying true SLNs is inadequate
in patients with tumours of the floor
of the mouth
-In cases of multiple SLNs and
SLNs at different levels, the number
of SLNs to be removed is still
unknown, which may lead to an
extensive procedure similar to that
of an END
-The 'shine through' phenomenon
and scatter radiation due to the
primary tumour can obscure
identification
-Variability in head and neck
lymphatic drainage may result in
collateral channels leading to skip
metastasis

$T 1=$ primary tumour of $\leq 2 \mathrm{~cm} ; \mathrm{T} 2=$ primary tumour of 2-4 cm; NO= without regional lymph node metastasis; SLN = sentinel lymph node; $E N D=$ elective neck dissection

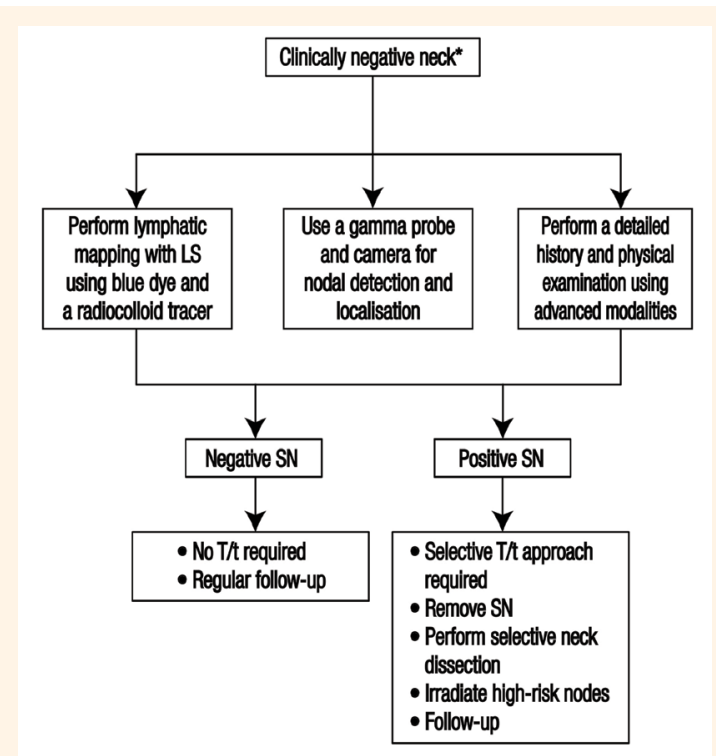

Figure 2: Proposed treatment protocol for a sentinel lymph node biopsy. ${ }^{30}$

"A clinically negative neck indicates a primary tumour of either $\leq 2$ cm or $2-4 \mathrm{~cm}$ with no regional lymph node metastasis. ${ }^{18}$ $L S G=$ lymphoscintigraphy $S N=$ sentinel node; $T / t=$ treatment.

statistically significant increased shoulder function and reduced average scar length among patients receiving a SLN biopsy in comparison to those undergoing END; neck haematomas and orocervical communication were reported only in the END group and SLN biopsies were associated with lower rates of postoperative morbidity. ${ }^{44}$

Alkureishi et al. reported that the pathological review of a SLN or neck dissection specimen can affect the staging of a lymph node if it reveals occult or additional positive lymph nodes which might have been missed on a routine physical examination or radiographical evaluation. ${ }^{43}$ This alteration in lymph node staging could increase the risk for distant metastasis and change the patient's prognosis and treatment plan. ${ }^{50,51}$ In HNSCC cases, a SLN biopsy has been suggested as a valid method to improve the accuracy of pathological staging of lymph nodes and subsequently allow treatments to be tailored. ${ }^{32}$ In a meta-analysis, Thompson et al. found that a positive SLN biopsy confirmed occult metastasis in $31 \%$ of patients; this correlates with a previously reported occult metastatic rate of $33 \% .{ }^{45,52}$

Evaluation of a positive lymph node status is critical as it is a major indicator for adjuvant radiation and chemotherapy. The use of a SLN biopsy allows adjuvant or elective chemoradiation to be avoided, as well as the associated morbidities of these treatment options. $^{53}$ For example, HNSCC patients receiving chemoradiation are more likely to develop acute mucositis, oral pain, dysphagia and xerostomia; in addition, they are more frequently hospitalised. ${ }^{45,54}$ Patients with a negative SLN biopsy can therefore 
avoid adjuvant therapy, which would lessen patient morbidity; this option can be reserved for a later time in the event of a second primary diagnosis or tumour recurrence. ${ }^{46}$ While a SLN biopsy is not yet considered the standard of care for cancers of the oral cavity, many single- and multi-centre studies have successfully demonstrated its feasibility in oral cancers with high detection rates (approximately 95\%) and negative predictive values (88-100\%), thus substantiating its significance and use in the staging and treatment of early-stage head and neck cancers. ${ }^{43,55,56}$

\section{Advances and Future Developments}

A variety of soluble tracers and radiocolloids have been used in lymphoscintigraphy, including technetium99m ( ${ }^{99 \mathrm{~m}} \mathrm{Tc}$ )-labelled colloidal human serum albumin, colloidal sulphur, ${ }^{99 \mathrm{~m}} \mathrm{Tc}$ colloidal rhenium sulphide and a dextran-based product modified to allow ${ }^{99}$ Tc-labelling. ${ }^{13,21,44,57}$ Tsuchimochi et al. proposed performing a SLN biopsy using multimodality imaging and polyamidoamine-coated silica nanoparticles loaded with ${ }^{99 \mathrm{~m}} \mathrm{Tc}$ and indocyanine green dye. ${ }^{47}$ Deeply situated SLNs can be detected more accurately with the use of near-infrared dyes; recently, hybrid tracers combined with radiotracers and fluorescence dyes have resulted in high sensitivity for preoperative SLN mapping. ${ }^{57}$ Bluemel et al. evaluated the feasibility and potential advantages of freehand SPECT in oral cancer in comparison with conventional intraoperative localisation techniques for a SLN biopsy; they found that one of the most important limitations of a SLN biopsy-the 'shine-through' phenomenon-was overcome by freehand SPECT. ${ }^{58}$

According to Denoth et al., metastatic deposits are not randomly distributed within SLNs but are predominantly found in the central planes, closer to the lymphatic inlet; analysis of the distribution pattern of metastatic spread within SLNs with a virtual microscope resulted in a detection rate of $90 \%$ and $80 \%$ for micrometastasis and ITCs, respectively. ${ }^{59}$ Van Den Berg et al. introduced the concept of hybrid tracers containing both radioactive and fluorescent labels which allowed for the direct integration of preand intraoperative guidance technologies when used in combination with new surgical imaging modalities and navigation tools in SLN detection. ${ }^{57}$ Using ultrasound-guided spectroscopic photoacoustic imaging of molecularly-activated plasmonic nanosensors in an OSCC murine model, Luke et al. demonstrated that lymph node metastases as small as $50 \mu \mathrm{m}$ could be detected in vivo at a depth of $1 \mathrm{~cm}$ with high sensitivity and specificity; this new approach could potentially be a sensitive alternative to a SLN biopsy. ${ }^{1}$

In various animal studies, attempts to combine several techniques have been reported, including the addition of ${ }^{99 \mathrm{~m}} \mathrm{Tc}$, iodine- 125 or iodine- 111 to phthalocyanine tetrasulfonate, dextran and Evans blue, methylene blue or blue Ficoll dyes. ${ }^{47,60}$ Tsopelas et al. found ${ }^{99 \mathrm{~m}} \mathrm{Tc}$-Evans blue to be useful in differentiating the initial draining lymph node from higher-tier nodes in linked chains. ${ }^{61}$ The clinical applications of a SLN biopsy could be enhanced through on-going developments and innovations. These might include the preoperative use of PET, the biological staging of primary site biopsies, the discovery of more radionuclide-avid lymph nodes or ultrasound-detectable injectable contrast agents as potential second tracers, the application of intraoperative reverse transcriptase polymerase chain reaction analysis of the sentinel node and the use of endoscopic SLN biopsies. ${ }^{14,26,27,62,63}$

\section{Conclusion}

A SLN biopsy can prevent the unnecessary removal of functional lymph nodes and limit the extent of neck dissection surgery. However, surgical precision and experience as well as specific technical devices are required for its successful application and implementation in the head and neck region. Although a review of the current literature demonstrated the reliability and worldwide acceptance of this approach, the role of SLN biopsies in HNSCCs is still under investigation. Using the sentinel node concept helps to define the surgical approach to a clinically negative neck and identify skip metastasis and unpredictable lymphatic drainage patterns, resulting in a more favourable prognosis for patients with head and neck cancers.

\section{References}

1. Luke GP, Myers JN, Emelianov SY, Sokolov KV. Sentinel lymph node biopsy revisited: Ultrasound-guided photoacoustic detection of micrometastases using molecularly targeted plasmonic nanosensors. Cancer Res 2014; 74:5397-408. doi: 10.1158/0008-5472.CAN-14-0796.

2. Klein CA. Parallel progression of primary tumours and metastases. Nat Rev Cancer 2009; 3:302-12. doi: 10.1038/nrc 2627.

3. Fidler IJ. Critical factors in the biology of human cancer metastasis: Twenty-eighth G.H.A. Clowes Memorial Award lecture. Cancer Res 1990; 50:6130-8.

4. Chen Z, Smith CW, Kiel D, Van Waes C. Metastatic variants derived following in vivo tumor progression of an in vitro transformed squamous cell carcinoma line acquire a differential growth advantage requiring tumor-host interaction. Clin Exp Metastasis 1997; 15:527-37. doi: 10.1023/A:1018474910432. 
5. Hermanek P, Hutter RV, Sobin LH, Wittekind C. International Union Against Cancer: Classification of isolated tumor cells and micrometastasis. Cancer 1999; 86:2668-73. doi: 10.1002/(SICI)1097-0142(19991215)86:12<2668::AID-CN CR11>3.0.CO;2-R

6. Čelakovský P, Kalfeřt D, Smatanová K, Chrobok V, Laco J. Detection of cervical lymph node micrometastases in patients with squamous cell carcinoma of the oral cavity, pharynx and larynx. Acta Medica (Hradec Kralove) 2015; 58:62-5. doi: 10.14712/18059694.2015.95.

7. Leong SP, Tseng WW. Micrometastatic cancer cells in lymph nodes, bone marrow, and blood: Clinical significance and biologic implications. CA Cancer J Clin 2014; 64:195-206. doi: $10.3322 /$ caac. 21217

8. Pereira ER, Jones D, Jung K, Padera TP. The lymph node microenvironment and its role in the progression of metastatic cancer. Semin Cell Dev Biol 2015; 38:98-105. doi: 10.1016/j. semcdb.2015.01.008

9. Gurney BA, Schilling C, Putcha V, Alkureishi LW, Alvarez AJ, Bakholdt $\mathrm{V}$, et al. Implications of a positive sentinel node in oral squamous cell carcinoma. Head Neck 2012; 34:1580-5. doi: 10.1002/hed.21973.

10. Baradaranfar $\mathrm{MH}$, Zahir ST, Atighechi S, Dadgarnia $\mathrm{MH}$ Bayati F, Mohajerani MR. Lymphatic metastasis in head and neck squamous cell carcinoma. Pak J Med Sci 2011; 27:303-6.

11. Longatto Filho A, Oliveira TG, Pinheiro C, de Carvalho MB, Curioni OA, Mercante AM, et al. How useful is the assessment of lymphatic vascular density in oral carcinoma prognosis? World J Surg Oncol 2007; 5:140. doi: 10.1186/1477-7819-5-140.

12. Noguti J, De Moura CF, De Jesus GP, Da Silva VH, Hossaka TA, Oshima CT, et al. Metastasis from oral cancer: An overview. Cancer Genomics Proteomics 2012; 9:329-35.

13. Essig H, Warraich R, Zulfiqar G, Rana R, Eckardt AM, Gellrich NC, et al. Assessment of cervical lymph node metastasis for therapeutic decision-making in squamous cell carcinoma of buccal mucosa: A prospective clinical analysis. World J Surg Oncol 2012; 10:253. doi: 10.1186/1477-7819-10-253.

14. Rakheja M, Radhakrishnan R, Solomon MC. Sentinel lymph node biopsy in oral squamous cell carcinoma: Ensuing from elective to selective. J Res Med Dent Sci 2014; 2:5-10. doi: 10.5455 /jrmds. 2014222 .

15. Sloan P. Head and neck sentinel lymph node biopsy: Current state of the art. Head Neck Pathol 2009; 3:231-7. doi: 10.1007/ s12105-009-0132-3.

16. Narendra H, Tankshali RA. Prevalence and pattern of nodal metastasis in pT4 gingivobuccal cancers and its implications for treatment. Indian J Cancer 2010; 47:328-31. doi: 10.4103/0019. 509X.64720

17. Byers RM, Weber RS, Andrews T, McGill D, Kare R, Wolf P. Frequency and therapeutic implications of "skip metastases" in neck from squamous cell carcinoma of oral tongue. Head Neck 1997; 19:14-19. doi: 10.1002/(SICI)1097-0347(199701) 19:1<14:AID-HED3>3.0.CO;2-Y.

18. Stevenson MM. Head and neck cancer staging: TNM classification for head and neck cancer. From: http://emedicine. medscape.com/article/2007181-overview Accessed: Sep 2016.

19. Russolo M, Giacomarra V, Papanikolla L, Tirelli G. Prognostic indicators of occult metastases in oral cancer. Laryngoscope 2002; 112:1320-3. doi: 10.1097/00005537-200207000-00035.

20. Ho CM, Lam KH, Wei WI, Lau SK, Lam LK. Occult lymph node metastasis in small oral tongue cancers. Head Neck 1992; 14:359-63. doi: 10.1002/hed.2880140504.

21. Pimenta Amaral TM, Da Silva Freire AR, Carvalho AL, Pinto CA, Kowalski LP. Predictive factors of occult metastasis and prognosis of clinical stages I and II squamous cell carcinoma of the tongue and floor of the mouth. Oral Oncol 2004; 40:780-6. doi: 10.1016/j.oraloncology.2003.10.009.
22. Chikamatsu K, Kamada H, Ninomiya H, Takahashi K, Sakurai T, Oriuchi N, et al. A preliminary study on sentinel lymph node biopsy: Feasibility and predictive ability in oral cavity cancer. Ann Nucl Med 2004; 18:257-62. doi: 10.1007/ BF02985008.

23. Ross GL, Soutar DS, MacDonald DG, Shoaib T, Camilleri IG, Robertson AG. Improved staging of cervical metastases in clinically node-negative patients with head and neck squamous cell carcinoma. Ann Surg Oncol 2004; 11:213-18. doi: 10.1245/ ASO.2004.03.057.

24. Melkane AE, Mamelle G, Wycisk G, Temam S, Janot F, Casiraghi $\mathrm{O}$, et al. Sentinel node biopsy in early oral squamous cell carcinomas: A 10-year experience. Laryngoscope 2012; 122:1782-8. doi: 10.1002/lary.23383.

25. Moreno-García C. Elective neck dissection in early oral squamous cell carcinoma: Necessary? Plast Aesthet Res 2016; 3:167-74. doi: 10.20517/2347-9264.2016.12.

26. Kurokawa H, Yamashita Y, Takeda S, Zhang M, Fukuyama H Takahashi T. Risk factors for late cervical lymph node metastases in patients with stage I or II carcinoma of the tongue. Head Neck 2002; 24:731-6. doi: 10.1002/hed.10130.

27. Calabrese L, Bruschini R, Ansarin M, Giugliano G, De Cicco C, Ionna $\mathrm{F}$, et al. Role of sentinel lymph node biopsy in oral cancer. Acta Otorhinolaryngol Ital 2006; 26:345-9.

28. Civantos FJ, Zitsch RP, Schuller DE, Agrawal A, Smith RB, Nason R, et al. Sentinel lymph node biopsy accurately stages the regional lymph nodes for T1-T2 oral squamous cell carcinomas: Results of a prospective multi-institutional trial. J Clin Oncol 2010; 28:1395-400. doi: 10.1200/JCO.2008.20.8777.

29. Alvarez Amézaga J, Barbier Herrero L, Pijoan del Barrio JI, Martín Rodríguez JC, Romo Simón L, Genolla Subirats J, et al. Diagnostic efficacy of sentinel node biopsy in oral squamous cell carcinoma: Cohort study and meta-analysis. Med Oral Patol Oral Cir Bucal 2007; 12:E235-43.

30. Shoaib T, Soutar DS, MacDonald DG, Camilleri IG, Dunaway DJ, Gray HW, et al. The accuracy of head and neck carcinoma sentinel lymph node biopsy in the clinically N0 neck. Cancer 2001; 91:2077-83. doi: 10.1002/1097-0142 (20010601)91:11<2077::AID-CNCR1235>3.0.CO;2-E.

31. Stefanicka P, Profant M, Duchaj B, Valach M, Gal V, Dolezal P, et al. Sentinel lymph node radiolocalization and biopsy in oral cavity and oropharynx mucosal squamous cell carcinoma. Bratisl Lek Listy 2010; 111:590-4.

32. Morton DL, Wen DR, Wong JH, Economou JS, Cagle LA, Storm FK, et al. Technical details of intraoperative lymphatic mapping for early stage melanoma. Arch Surg 1992; 127: 392-9. doi: 10.1001/archsurg.1992.01420040034005.

33. Antonio JK, Santini S, Politi D, Sulfaro S, Spaziante R, Alberti A, et al. Sentinel lymph node biopsy in squamous cell carcinoma of the head and neck: 10 years of experience. Acta Otorhinolaryngol Ital 2012; 32:18-25.

34. Milenović A, Virag M, Kneević P, Boras VV, Ostović KT, Pandurić DG, et al. Evaluation of sentinel node biopsy in oral carcinomas. Coll Antropol 2014; 38:279-82.

35. Werner JA, Dünne AA, Ramaswamy A, Folz BJ, Lippert BM, Moll $R$, et al. Sentinel node detection in N0 cancer of the pharynx and larynx. Br J Cancer 2002; 87:711-15. doi: 10.1038/ sj.bjc. 6600445

36. Broglie MA, Haile SR, Stoeckli SJ. Long-term experience in sentinel node biopsy for early oral and oropharyngeal squamous cell carcinoma. Ann Surg Oncol 2011; 18:2732-8. doi: 10.1245/ s10434-011-1780-6.

37. Borbón-Arce $M$, Brouwer OR, van den Berg NS, Mathéron $H$, Klop WM, Balm AJ, et al. An innovative multimodality approach for sentinel node mapping and biopsy in head and neck malignancies. Rev Esp Med Nucl Imagen Mol 2014; 33:274-9. doi: 10.1016/j.remn.2013.11.005. 
38. Rigual N, Loree T, Frustino J, Jayaprakash V, Cohan D, Sullivan M, et al. Sentinel node biopsy in lieu of neck dissection for staging oral cancer. JAMA Otolaryngol Head Neck Surg 2013; 139:779-82. doi: 10.1001/jamaoto.2013.3863.

39. Flach GB, Bloemena E, Klop WM, van Es RJ, Schepman KP, Hoekstra OS, et al. Sentinel lymph node biopsy in clinically NO T1-T2 staged oral cancer: The Dutch multicenter trial. Oral Oncol2014;50:1020-4. doi:10.1016/j.oraloncology.2014.07.020.

40. Den Toom IJ, Heuveling DA, Flach GB, van Weert S, Karagozoglu KH, van Schie A, et al. Sentinel node biopsy for early-stage oral cavity cancer: The VU University Medical Center experience. Head Neck 2015; 37:573-8. doi: 10.1002/ hed.23632.

41. Salazar-Fernandez CI, Gallana-Alvarez S, Pereira S, Cambill T, Infante-Cossio P, Herce-Lopez J. Sentinel lymph node biopsy in oral and oropharyngeal squamous cell carcinoma: Statistical validation and impact of micrometastasis involvement on the neck dissection decision. J Oral Maxillofac Surg 2015, 73:1403-9. doi: 10.1016/j.joms.2015.01.033.

42. Coughlin A, Resto VA. Oral cavity squamous cell carcinoma and the clinically n0 neck: The past, present, and future of sentinel lymph node biopsy. Curr Oncol Rep 2010; 12:129-35. doi: 10.1007/s11912-010-0090-7.

43. Alkureishi LW, Ross GL, Shoaib T, Soutar DS, Robertson AG, Thompson R, et al. Sentinel node biopsy in head and neck squamous cell cancer: 5-year follow-up of a European multicenter trial. Ann Surg Oncol 2010; 17:2459-64. doi: 10.1245/s10434-010-1111-3.

44. Hernando J, Villarreal P, Alvarez-Marcos F, Gallego L, GarcíaConsuegra L, Junquera L. Comparison of related complications: Sentinel node biopsy versus elective neck dissection. Int J Oral Maxillofac Surg 2014; 43:1307-12. doi: 10.1016/j.ijom. 2014.07.016.

45. Thompson CF, St John MA, Lawson G, Grogan T, Elashoff D, Mendelsohn AH. Diagnostic value of sentinel lymph node biopsy in head and neck cancer: A meta-analysis. Eur Arch Otorhinolaryngol 2013; 270:2115-22. doi: 10.1007/s00405012-2320-0.

46. Hassan O, Taha MS, El Mehairy H. Sentinel lymph node biopsy versus elective neck dissection in evaluation of cN0 neck in patients with oral and oropharyngeal squamous cell carcinoma: Systematic review and meta-analysis study. Egypt J Ear Nose Throat Allied Sci 2015; 16:25-34. doi: 10.1016/j. ejenta.2014.10.001

47. Tsuchimochi M, Hayama K, Toyama M, Sasagawa I, Tsubokawa N. Dual-modality imaging with $99 \mathrm{mTc}$ and fluorescent indocyanine green using surface-modified silica nanoparticles for biopsy of the sentinel lymph node: An animal study. EJNMMI Res 2013; 3:33. doi: 10.1186/2191-219X-3-33.

48. Stoeckli SJ, Pfaltz M, Ross GL, Steinert HC, MacDonald DG, Wittekind $\mathrm{C}$, et al. The second international conference on sentinel node biopsy in mucosal head and neck cancer. Ann Surg Oncol 2005; 12:919-24. doi: 10.1245/ASO.2005.11.024

49. Murer K, Huber GF, Haile SR, Stoeckli SJ. Comparison of morbidity between sentinel node biopsy and elective neck dissection for treatment of the n0 neck in patients with oral squamous cell carcinoma. Head Neck 2011; 33:1260-4. doi: $10.1002 /$ hed. 21622 .

50. Kapoor C, Vaidya S, Wadhwan V, Malik S. Lymph node metastasis: A bearing on prognosis in squamous cell carcinoma. Indian J Cancer 2015; 52:417-24. doi: 10.4103/0019-509X. 176750 .
51. Greenberg JS, El Naggar AK, Mo V, Roberts D, Myers JN. Disparity in pathologic and clinical lymph node staging in oral tongue carcinoma: Implication for therapeutic decision making. Cancer 2003; 98:508-15. doi: 10.1002/cncr.11526.

52. Shah JP. Patterns of cervical lymph node metastasis from squamous carcinomas of the upper aerodigestive tract. Am J Surg 1990; 160:405-9. doi: 10.1016/S0002-9610(05)80554-9.

53. Höft S, Maune S, Muhle C, Brenner W, Czech N, Kampen WU, et al. Sentinel lymph-node biopsy in head and neck cancer. Br J Cancer 2004; 91:124-8. doi: 10.1038/sj.bjc.6601877.

54. Trotti A, Bellm LA, Epstein JB, Frame D, Fuchs HJ, Gwede CK, et al. Mucositis incidence, severity and associated outcomes in patients with head and neck cancer receiving radiotherapy with or without chemotherapy: A systematic literature review. Radiother Oncol 1997; 66:253-62. doi: 10.1016/S0167-8140(02) 00404-8.

55. Ramamurthy R, Kottayasamy Seenivasagam R, Shanmugam S, Palanivelu K. A prospective study on sentinel lymph node biopsy in early oral cancers using methylene blue dye alone. Indian J Surg Oncol 2014; 5:178-83. doi: 10.1007/s13193-0140337-0.

56. Hart RD, Nasser JG, Trites JR, Taylor SM, Bullock M, Barnes D. Sentinel lymph node biopsy in N0 squamous cell carcinoma of the oral cavity and oropharynx. Arch Otolaryngol Head Neck Surg 2005; 131:34-8. doi: 10.1001/archotol.131.1.34.

57. Van Den Berg NS, Buckle T, Kleinjan GI, Klop WM, Horenblas S, Van Der Poel HG, et al. Hybrid tracers for sentinel node biopsy. Q J Nucl Med Mol Imaging 2014; 58:193-206.

58. Bluemel C, Herrmann K, Kübler A, Buck AK, Geissinger E, Wild $\mathrm{V}$, et al. Intraoperative 3-D imaging improves sentinel lymph node biopsy in oral cancer. Eur J Nucl Med Mol Imaging 2014; 41:2257-64. doi: 10.1007/s00259-014-2870-z.

59. Denoth S, Broglie MA, Haerle SK, Huber GF, Haile SR, Soltermann A, et al. Histopathological mapping of metastatic tumor cells in sentinel lymph nodes of oral and oropharyngeal squamous cell carcinomas. Head Neck 2015; 37:1477-82. doi: $10.1002 /$ hed.23782

60. Kogashiwa Y, Sakurai H, Akimoto Y, Sato D, Ikeda T, Matsumoto Y, et al. Sentinel node biopsy for the head and neck using contrast-enhanced ultrasonography combined with indocyanine green fluorescence in animal models: A feasibility study. PLoS One 2015; 10:e0132511. doi: 10.1371/journal. pone.0132511.

61. Tsopelas C, Bellon M, Bevington E, Kollias J, Shibli S, Chatterton BE. Lymphatic mapping with $99 \mathrm{mTc}$-Evans blue dye in sheep. Ann Nucl Med 2008; 22:777-85. doi: 10.1007/s12149008-0171-y.

62. Yamazaki Y, Saitoh M, Notani K, Tei K, Totsuka Y, Takinami S, et al. Assessment of cervical lymph node metastases using FDG-PET in patients with head and neck cancer. Ann Nucl Med 2008; 22:177-84. doi: 10.1007/s12149-007-0097-9.

63. Alkureishi LW, Burak Z, Alvarez JA, Ballinger J, Bilde A, Britten $\mathrm{AJ}$, et al. Joint practice guidelines for radionuclide lymphoscintigraphy for sentinel node localization in oral/ oropharyngeal squamous cell carcinoma. Eur J Nucl Med Mol Imaging 2009; 36:1915-36. doi: 10.1007/s00259-009-1248-0. 